\title{
Znaczenie Internetu dla zarządzania reputacją naukowca
}

\section{Wprowadzenie}

Praca człowieka nauki powinna przynosić mu wiele zadowolenia, satysfakcji oraz spełnienia. Często dzieje się tak wówczas, gdy wykonywana praca jest powołaniem. „Idea pracy uczonego jako «zawodu-powołania» wywodzi się od Arystotelesa - z jego modelu statusu i funkcji człowieka nauki. Kontynuacją był model nauki zaprezentowany przez awerroistów łacińskich. Także (...) pozytywizm pojmuje pracę uczonego jako «zawód-powołanie»"1. Człowiek decydujący się na wykonywanie zawodu uczonego przyjmuje na siebie dwa rodzaje powinności: zarówno wobec nauki jak i wobec siebie. Do obowiązków naukowca wobec nauki należy prowadzenie nowatorskich badań, rozpowszechnianie ich wyników w celu przyczynienia się do rozwoju własnej dyscypliny naukowej, motywacja w poszukiwaniu nowych sytuacji problemowych, pracowitość i sumienność oraz uczciwość, a także wychowywanie nowych pokoleń naukowców, będąc dla nich wzorcem etosu akademickiego podczas podejmowania nowych wyzwań. Spełniane powinności naukowca wobec siebie to dążenie do osiągnięcia stabilizacji zawodowej, ekonomicznej, uzyskiwanie statusu i funkcji wysoce cenionego

$\overline{1}$ J. Goćkowski, Ethos nauki i role uczonych, Wydawnictwo i Drukarnia Secesja, Kraków 1996, s. 38. 
specjalisty w środowisku oddziałującym na dalszy przebieg biografii zawodowej. Szczególnie ważnym jest obowiązek uzyskiwania uznania, zaufania i wiarygodności społecznej. W wypełnianiu obowiązków naukowca wobec nauki i wobec siebie dużą rolę odgrywają reputacja i składające się na nią wizerunki. Jak trafnie stwierdził Jerzy Altkorn „każdy przedmiot, osoba, zjawisko, jeśli tylko zwrócimy na nie uwagę, uzyskuje w naszej świadomości jakiś wizerunek", co oznacza, że wizerunek „to właśnie subiektywne wyobrażenie, które posiadamy o obiekcie naszego zainteresowania"2. Podstawą naszego wyobrażenia na temat danej osoby, są zarówno informacje, które czerpiemy z własnych spostrzeżeń, przemyśleń, jak te, które docierają za pomocą różnych źródeł informacyjnych. Jednym z nich, z których czerpiemy nieograniczone ilości informacji są nowe media.

Internet jest dziś jednym z narzędzi nowych mediów. Obecnie pod pojęciem „nowe media" rozumie się całokształt komunikatów oraz narzędzia technologii informacyjnej, jakimi dysponuje człowiek. To właśnie nowe media dały początek rewolucji na przełomie XX i XXI wieku określanej mianem rewolucji informacyjnej bądź elektronicznej. (...) Powszechny dostęp do Internetu spopularyzował nowe pojęcie cyberprzestrzeni, które zostało użyte po raz pierwszy w 1984 roku przez Williama Gibsona w pierwszym tomie trylogii Burning Chrome zatytułowanym Neuromancer. „Cyberprzestrzeń w dzisiejszym rozumieniu to przestrzeń otwartego komunikowania się za pośrednictwem połączonych komputerów i pamięci informatycznych pracujących na całym świecie. W dyskursie humanistycznym stała się ona zatem synonimem Internetu"3.

Gwałtowny rozwój nowych mediów oraz dynamiczna ekspansja technologii informacyjno-komunikacyjnej zrewolucjonizowała praktycznie wszystkie dziedziny ludzkiego życia, w tym także nauki. Dlatego tak istotne jest, aby wszyscy naukowcy podjęli działania w celu zarządzania reputacją przy użyciu dostępnych narzędzi jednego z najbardziej popularnych mediów, jakim jest Internet. Daje to szansę, przy zachowaniu obowiązujących zasad etycznych, na wykreowanie własnego wizerunku, będącego kanwą pożądanej, wiarygodnej dla otoczenia reputacji.

2 J. Altkorn, Kształtowanie rynkowego wizerunku firmy, Wydawnictwo Akademii Ekonomicznej, Kraków 2009, s. 9.

3 Cyt. za A. Pawiak, A. Cyberprzestrzeń jako „forum” oddziałujace na młode pokolenia w refleksji Jana Pawła II, „Rozprawy Społeczne” 2015, nr 9/4, s. 85. 


\section{Znaczenie tożsamości i wizerunku dla formowania reputacji}

Tożsamość jest odzwierciedleniem rzeczywistych właściwości podmiotu. Odpowiada charakterowi osób, stanowiącemu ich „utrwalone rysy osobowościowe, wyrażające się w określonych stałych sposobach postępowania, niezależnych od sytuacji, w jakiej dana osoba się znajduje"4. Nie można jednak uznać, że tożsamość jest wiernie odwzorowywana w wizerunkach. Osoby posiadające wizję, jak chciałyby, aby je postrzegało otoczenie, nie mogą stworzyć całkowicie sztucznego obrazu, „w pełni oderwanego od ich rzeczywistych cech, ale mogą starać się wyeksponować te cechy, które są zgodne z pożądanym wyobrażeniem. W ten sposób na styku tożsamości i pożądanego wizerunku rodzi się zakładany kształt obrazu danego podmiotu, na bazie formułowanego, intencjonalnego przekazu do otoczenia". Pamiętać jednak należy, że „tożsamość wpływa na wizerunek, który z kolei kształtuje reputację. Tym samym reputacja jest sumą cząstkowych, nagromadzonych w czasie wizerunków"6. Steuart Henderson Britt definiując wizerunki wskazał, że są one „publicznymi stereotypami i gdy stereotyp się ukształtuje, ludzie w większym stopniu działają pod jego wpływem niż pod wpływem tego, co się za nim kryje"7. Eleri Sampson porównuje wizerunek do reklamy, proponując czytelnikowi swej książki Jak tworzyć własny wizerunek?, aby spróbował wyobrazić sobie własny wizerunek jako zewnętrzny obraz prezentujący jego najlepsze walory. Ważne jest jednak, aby ten zewnętrzny wizerunek odpowiadał umiejętnościom, zdolnościom i wartościom reklamującej się osoby.

Spytaj sam siebie - mówi E. Sampson - co chcesz powiedzieć ludziom o swych zamierzeniach i możliwościach. Każdy człowiek ma swoje określone zasady, dzięki którym może być rozpoznany. Nie tylko ubrania składają się na wizerunek. Twój

4 T. Dąbrowski, Rola mediów w kształtowaniu wizerunku, „Marketing i Rynek” 2013, nr 9, s. 10.

5 Ibidem, s. 11.

$6 \quad$ K. Majchrzak, Zarządzanie reputacją korporacyjna we współczesnej gospodarce, [w:] R. Maćkowska, H. Przybylski (red.), Public relations - aktualne zagadnienia sztuki komunikowania w teorii i praktyce, Wydawnictwo Akademii Ekonomicznej, Katowice 2009, s. 291.

7 S.H. Britt, Psychological Principles of the Corporate Imagery Mix, „Business Horizons" 1971, 14/1, s. 55. 
wizerunek to wypracowana mieszanka czynników zewnętrznych i wewnętrznych określających wizerunek własny, widzialny i wizerunek pożądany .

W literaturze tematu często wizerunek utożsamiany jest $\mathrm{z}$ reputacją. Słowo reputacja „pochodzi od łacińskiego «reputatio» i pierwotnie oznaczało «rozważenie» lub «oszacowanie». Później zyskało znaczenie publicznej oceny na temat jakiejś osoby". Jak stwierdza Susanna Wiesender i Thomas Cerny:

reputacja powstaje na podstawie wielokrotnych obserwacji i stanowi wyraz uznania rozpowszechniany poprzez osobiste znajomości, ale także wykraczający poza indywidualną sieć kontaktów, na przykład w przypadku wzmianek w mediach. W takiej sytuacji reputacja powstaje automatycznie, niezależnie od tego, czy ktoś próbuje na nią wpłynąć, czy też nie ${ }^{9}$.

Osobę cieszącą się dobrą reputacją charakteryzuje powtarzanie pozytywnych działań i stawanie się przez to godną zaufania, spełnianie oczekiwań poprzez odgrywanie roli w kontekście przyjętych i akceptowalnych wartości i założeń moralnych. Posiada ona umiejętności podkreślania własnej odmienności i nieprzeciętności. W celu odróżnienia pojęcia wizerunku od reputacji można posłużyć się obrazowym porównaniem. O ile reputacje można porównać do książeczki oszczędnościowej, posiadanej przez właściciela przez dłuższy czas, a nawet przez całe życie, o tyle wizerunek jest rachunkiem rozliczeniowym, na którym suma może zarówno szybko rosnąć, jak i spadać w wyniku nieoczekiwanych wahań. W karierze zawodowej naukowiec zbiera osobisty kapitał, a korzyści uzyskiwane na podstawie dobrej opinii stanowią odsetki, dzięki którym osiąga się poczucie bezpieczeństwa, buduje zaufanie, staje się wiarygodnym ${ }^{10}$. Kształtowanie wizerunku opiera się w dużej mierze na komunikacji, a sam wizerunek nie musi w pełni być odzwierciedleniem rzeczywistości. Kształtowanie reputacji opiera się na substancjalnych działaniach podmiotu.

$8 \quad$ E. Sampson, Jak tworzyć własny wizerunek, przekł. A. Białkowska-Gużyńska, Dom Wydawniczy ABC, Warszawa 1996, s. 14-15.

$9 \quad$ S. Wieseneder, T. Cerny, Skuteczne zarządzanie reputacją i spójny image, Wydawnictwo BestPress, Warszawa 2008, s. 37.

10 Ibidem, s. 41. 


\title{
Czynniki kreujące wizerunek
}

Formowanie się wizerunku następuje w wyniku interakcji zachodzących między czynnikami związanymi z podmiotami, których wizerunek jest kształtowany przekazem, jaki trafia do odbiorców oraz czynnikami odnoszącymi się do jednostki będącej odbiorcą prze$\mathbf{k a z u}^{11}$. Ważną rolę w pierwszej grupie czynników odpowiedzialnych za wizerunek odgrywa tożsamość, o której była mowa w poprzedniej części artykułu. Przekaz, który zaliczany jest do drugiej grupy często podlega oddziaływaniom osób, które starały się wpłynąć na jego formę i treści. Poza przekazem intencjonalnym, który może być w pełni kontrolowany za pomocą różnych środków pozwalających nadawcy w większym lub mniejszym stopniu oddziaływać na informacje dostarczane odbiorcom, może również docierać przekaz nieintencjonalny ze źródeł niezależnych. Przekaz intencjonalny ukierunkowany na budowanie założonego wizerunku pochodzi od jego właściciela, który próbuje wywierać wpływ na otoczenie. Przekazy nieintencjonalne

\begin{abstract}
z punktu widzenia założonego wizerunku mogą mieć charakter neutralny, a nawet mogą stać z nim w sprzeczności. Przekazy te przybierają formę pogłoski bądź plotki, mogą też stanowić opinię na temat danego podmiotu pochodzącą z niezwiązanych z nim źródeł. Oddziaływanie przekazów nieintencjonalnych na wizerunek jest znaczące, traktowane są one bowiem na ogół jako bardziej wiarygodne od przekazów intencjonalnych ${ }^{12}$. Wizerunek kształtuje się również pod wpływem bezpośrednich doświadczeń związanych z osobistym kontaktem z daną osobą.
\end{abstract}

\section{Czynniki odnoszące się do samych odbiorców stanowią trze-} cią grupę oddziałującą na wizerunek. W zależności od cech odbiorcy, takich jak: zdolności percepcyjne, siatki schematów poznawczych, przekonania, postawy czy systemy wartości, przekazy docierające do odbiorców podlegają indywidualnej interpretacji. Analiza odebranego komunikatu uwarunkowana jest również jego wcześniejszymi wyobrażeniami dotyczącymi danego podmiotu czy postrzeganej całościowo sfery działalności. Informacje, które są zgodne z przekonaniami, postawami i wartościami odbiorcy bądź jego dotychczasowym wyobrażeniem oraz są koherentne z postrzeganą działalnością ocenianego

11 T. Dąbrowski, Rola mediów..., s. 12.

12

Ibidem, s. 11. 
podmiotu zostają lepiej zapamiętane. Wszystkie przekazy sprzeczne i niespójne są albo ignorowane albo zmodyfikowane ${ }^{13}$.

\section{Wiarygodność reputacji a pozór rzeczywistości}

Jedną z trzech kategorii wiarygodności, dotyczących informacji poszukiwanych i wykorzystywanych w celu dokonania oceny, poza wiarygodnością inferowaną i wymuszoną, stanowi wiarygodność immanentna. Odnosi się ona do czynników, związanych z cechami osoby obdarzanej zaufaniem, dotyczy cech dostępnych poznawczo z zewnątrz, które dają się określić bardziej bezpośrednio. Oprócz rekomendacji, referencji i prezentacji partnera w działaniu podkreśla się w niej znaczenie wizerunku i reputacji. Reputacja w opinii Piotra Sztompki określona została jako „wcześniejsze działania partnera, które mogą wskazywać na jego wiarygodność także w przyszłości" ${ }^{14}$.

Według Russella Hardina reputacja jest wyznacznikiem skłonności do określonych działań, pozwala przewidzieć, w jaki sposób osoba może się zachować w konkretnej sytuacji. Zadaje on jednak pytanie: co jest powodem, że reputacja odgrywająca tak ważną rolę w życiu społecznym, motywuje osobę do utrzymania posiadanej już dobrej opinii? „Znaczenie reputacji przekracza zawieranie się interesów, na których opierają się pośrednie relacje. Dobra opinia zachęca innych do podjęcia z nami współpracy, z której korzyści czerpią obie strony”15. W literaturze wyróżnia się reputacje pierwotną (bezpośrednią) i wtórną (pośrednią). Reputacja pierwotna to wiarygodne i długotrwałe postępowanie jej właściciela. Tworzy się w wyniku osobistej rozmowy lub kontaktu z osobą. Jej podstawą są przewidywalne, zgodne z oczekiwaniami i wyjątkowe zachowania. Reputacja wtórna powstaje na bazie informacji czerpanych z otoczenia przez zbieranie o kimś informacji od osób trzecich, sprawdzanie referencji, uzyskiwanie opinii. Czynniki wpływające w pierwszej kolejności na opinie to pochodzenie, wybór szkoły, uczelni czy też pierwszej pracy, znajomość zasad właściwego zachowania, często ocenianego na podstawie tradycyjnych wartości,

\footnotetext{
$\overline{13}$ Ibidem, s. 12.

14 P. Sztompka, Zaufanie. Fundament społeczeństwa, Wydawnictwo Znak, Kraków 2007, s. 226.

15 R. Hardin, Zaufanie, przekł. A. Gruba, Wydawnictwo Sic!, Warszawa 2009, s. 32.
} 
takich jak: uczciwość, lojalność, solidność, wiarygodność, właściwe traktowanie pracowników, unikanie nieetycznych zachowań, odważne podejmowanie decyzji w sytuacjach konfliktowych, kryzysowych. Poza tym umiejętność ubrania się stosownie do okoliczności, społeczna i emocjonalna bliskość z osobami, które odniosły już sukces zawodowy. Również P. Sztompka stwierdza, że najcenniejszym wskaźnikiem naszej wiarygodności w budowaniu reputacji jest to z kim się spotykamy, przyjaźnimy, w jakim otoczeniu funkcjonujemy. „Sprytni manipulatorzy starają się znaleźć na zdjęciu z kimś znanym i ważnym albo przynajmniej wepchnąć się gdzieś w pobliże takiej osoby"16. Wiąże się to $\mathrm{z}$ jednym z czynników tworzenia reputacji, jakim jest zauważalność. W myśl stwierdzenia: opinia powstaje na podstawie ciągłego komunikowania się, a bycie systematycznym tematem rozmów otoczenia jak najbardziej temu służy. Czy w przypadku naukowców również można mówić o zauważalności, gwiazdorstwie, a może celebrytach naukowych? Funkcjonują dwa odmienne podejścia dotyczące celebrytów. „W ramach pierwszego z nich traktowani są oni jako osoby zasługujące na otaczającą je sławę ze względu na wyjątkowe talenty, osiągnięcia i osobowośc" ${ }^{17}$. Odnieśmy to do „celebrytów nauki”, mistrzów w jak najlepszym tego słowa znaczeniu. Mimo że

określenie „mistrz” staje się raczej odświętną metaforą niż kategorią potwierdzającą wagę autorskiej twórczości, jej ciągłość i możliwość rozwijania z zachowaniem wierności zawartym w niej słowom i ideom. Z mistrzostwem wiązać wypada natomiast najwyższy poziom wiarygodności, choćby z uwagi na jego niekwestionowany autorski wymiar oraz zakres potwierdzanych i uznanych kompetencji ${ }^{18}$.

Druga definicja celebrytów podkreśla wykreowanie osoby, przy jej udziale, gdzie popularność jest rezultatem celowych, zaplanowanych działań zwiększających widoczność, zauważalność w mediach, co prowadzi do tego, że są one „znane z tego, że są znane”. Jak słusznie zauważa Jacek Piekarski, w czasach, w których żyjemy

\footnotetext{
16 P. Sztompka, Zaufanie. Fundament..., s. 184.

17 T. Dąbrowski, Rola mediów..., s. 14.

18 J. Piekarski, Dlaczego pytamy o wiarygodność? Pogranicza dyscyplinarne w praktyce akademickiej, [w:] J. Piekarski, D. Urbaniak-Zając (red.), Wiarygodność akademicka w edukacyjnych praktykach, Wydawnictwo Uniwersytetu Łódzkiego, Łódź 2016, s. 41.
} 
wątpienie w kompetencje staje się wstydliwe - podobnie jak krępujące bywa mówienie o prawdzie czy też wiarygodności - a ujawnianie związanych z nimi wątpliwości marginalizowane. Uczciwe radzenie sobie $\mathrm{z}$ niekompetencją niejednokrotnie przegrywa w starciu z przymusem wykazywania się (często jedynie pozorowanym) znawstwem. Miejsce otwartego wątpienia w kompetencje (własne i innych) zajmuje eksponowane dążenie do bieżącego dysponowania trafnymi i oczekiwanymi odpowiedziami - wiarygodność przegrywa w konfrontacji z poprawnością, a zaufanie - tą drogą inscenizowane $-\mathrm{z}$ oswojoną nieufnością. (...) Troskę o „mistrzostwo” - kultywowane jako wyznacznik wiarygodności - zdaje się zastępować imperatyw znawstwa, skłaniający do określonego sposobu prezentowania własnego wizerunku ${ }^{19}$.

Niekompetencje ukrywane są za zasłoną rzekomego oczytania, szerokich horyzontów myślowych, uczoności, przy jednoczesnym doskonaleniu odpowiednich środków stosowanych w celu wywoływania dużego wrażenia na otoczeniu.

Zmiany dokonujące się w estetyce uczestnictwa w kulturze akademickiej są powszechnie dostrzegane. Jej elementem (...) staje się tworzenie własnego wizerunku poprzez epizodyczne i partykularne inscenizowanie w niej własnej obecności. Dostrzega się towarzyszący temu pozór, imitowanie wiedzy oraz cynizm, stanowiące podłoże kształtowania się akademickiego gwiazdorstwa ${ }^{20}$.

\section{Cyfrowi tubylcy}

Duża dostępność, interaktywność i różnorodność form oraz szybkość przekazu komunikatów powodują, że Internet jest nieodłącznym medium komunikowania się w każdej dziedzinie życia, w tym również obszarze zawodowym. Nie wszyscy naukowcy zdają sobie z tego sprawę, że ich działalność naukowa, zachowania są przedmiotem często bacznej obserwacji, wnikliwych komentarzy oraz ocen ich postępowania nie tylko w świecie rzeczywistym, ale również w cyberprzestrzeni. Bycie uczestnikiem cyberprzestrzeni umożliwia zorientowanie się w działaniach prowadzonych przez innych naukowców, daje szanse podejmowania dyskusji, spojrzenia na podejmowane tematy szerzej i z różnych perspektyw. Jest miejscem wymiany doświadczeń, a opinie naukowców są dla szerokiej rzeszy odbiorców dodatkową okazją do

\footnotetext{
19 Ibidem, s. 42.

20 L. Witkowski, Wyzwania autorytetu w praktyce społecznej $i$ kulturze symbolicznej, Oficyna Wydawnicza „Impuls”, Kraków 2009, s. 262-267.
} 
zdobywania i poszerzania wiedzy ${ }^{21}$. Sposób prezentowania informacji na swój sposób za pomocą Internetu jest obecnie znacznie bardziej dynamicznym, złożonym i efektywniejszym procesem, niż rozpowszechnianie wyników badań za pomocą tradycyjnych metod, jak tylko poprzez publikacje naukowe czy konferencje. Jednak naukowcy muszą być gotowi na cenzurę, opinie często niezgodne z oczekiwaniami czyli wymaga się od nich akceptacji dla bycia nieustannie ocenianym i krytykowanym ${ }^{22}$.

Cyfrowi tubylcy nadający i odbierający komunikaty przekazują informacje na temat poszczególnych osób i ich zachowań często bez udziału zainteresowanych.

Stosowane wtedy metody komunikacji (logistyka reputacji) są bardzo złożone. Sięgają od pozytywnych pochwał przez formy neutralne (...) po działanie negatywne, na przykład zniesławienia czy wymuszenia. Często w przypadku ataku na reputacje nie wiadomo, kto go dokonał lub się do niego przyczynił. Jedynie w przypadku bezpośrednich oskarżeń znamy przeciwnika ${ }^{23}$.

Należy mieć na uwadze, że negatywne opinie są niejednokrotnie wynikiem korzystania z Internetu przez zwykłych ludzi niemających do czynienia $\mathrm{z}$ działaniami w obszarze zawodowym posiadacza reputacji, dlatego też osoby te nie są w stanie dokładnie, profesjonalnie ocenić działań i osiągnięć specjalistów w danej dziedzinie. Reputacja naukowców jest wypadkową różnych opinii, na które składają się elementy, zarówno racjonalne, jak i emocjonalne. Ma ona znamiona subiektywności, co jest wynikiem prezentowanych osądów na temat właściciela reputacji przez osoby o odrębnych poglądach, prezentujących różne wartości, posiadających rozmaite oczekiwania i interesy własne. Składają się na nią odmienne wyobrażenia, czyli wizerunki. Wyobrażenia ludzi na temat naukowców kształtowane są na podstawie często różnych rodzajów informacji pozyskiwanych z wielu źródeł.

$\overline{21}$ J. Pruchnicka, Media Relations - promocja nauki i instytucji badawczych w mediach w Polsce i Europie, „Marketing Instytucji Naukowych i Badawczych” 2012, nr 1(2), s. 168.

22 E. Głuszek, Kreowanie reputacji przedsiębiorstwa $w$ mediach społecznościowych szanse i zagrożenia, „Zarządzanie i Finanse” 2013, nr 4/1, s. 62.

23 S. Wieseneder, T. Cerny, Skuteczne zarządzanie reputacja i spójny image..., s. 153. 


\section{Zarządzanie reputacją z wykorzystaniem narzędzi internetowych}

Internet stał się nieodłącznym medium komunikowania się, a nieustanny wzrost jego użytkowników, wysoka dostępność, interaktywność i różnorodność form przekazu oraz szybkość komunikacji sprawiają, że wzrasta jego znaczenie jako medium komunikacji międzyludzkiej. I to powoduje konieczność aktywnego zarządzania reputacją z wykorzystaniem tego narzędzia dla „nowych możliwości skutecznego budowania wizerunku, jakie daje Internet, oraz ze zwiększonego ryzyka utraty reputacji związanego ze specyfiką funkcjonowania komunikacji w sieci" ${ }^{24}$.

Odwołując się do interpretacji potencjalnych korzyści dla kreowania wizerunku firmy w sieci, warto analogicznie odnieść się do korzyści płynących z budowania wizerunku naukowca, przeanalizować je w kontekście wykorzystywania przez niego różnych narzędzi internetowych.

Pierwszym proponowanym narzędziem jest strona www. Przykładowe korzyści związane $\mathrm{z}$ posiadaniem strony internetowej to możliwość: pełnienia roli wirtualnej wizytówki będącej, przejrzystą, sprawnie działającą i często aktualizowaną bazą danych. Prezentowania się szerokiemu gremium przy niewielkich nakładach dużej ilości informacji na własny temat; otrzymania feedbacku od różnych np. zainteresowanych grup dyskusyjnych; dwukierunkowej komunikacji z osobami o podobnej tematyce badawczej z całego świata poprzez udostępnienie adresu e-mail, identyfikatora komunikatora internetowego, formularza do wpisywania uwag, możliwości i wyrażać swojej opinii; możliwość zaprezentowania się jako kompetentnej osoby w danej dziedzinie nauki, eksperta w swej branży chętnie dzielącego się swoją wiedzą i doświadczeniem, odpowiedzialnego i wiarygodnego.

Odkąd Internet stał się powszechnie wykorzystywanym źródłem informacji, w środowisku naukowym zrodził się zwyczaj sprawdzania wiarygodności świeżo

24 E. Głuszek, Kreowanie reputacji przedsiębiorstwa w sieci - nowe możliwości komunikowania z interesariuszami, [w:] J. Skalik, A. Wierzbic, M. Wąsowicz (red.), Trendy transformacji modelu organizacyjnego przedsiębiorstwa, Wydawnictwo Uniwersytetu Ekonomicznego, Wrocław 2012, s. 78. 
poznanych kolegów lub autorów przeczytanych właśnie książek przez wyszukiwanie w katalogach Biblioteki Kongresu Stanów Zjednoczonych lub British Library bibliografii lub ich publikacji. $\mathrm{Z}$ tego samego powodu powstają $\mathrm{w}$ Internecie prywatne strony, na których można znaleźć informacje biograficzne o różnych osobach $^{25}$.

Drugim narzędziem, z którego można korzystać dla budowania własnej reputacji w sieci jest fanpage na Facebooku lub innym portalu społecznościowym. Dają one m.in. możliwość uzyskania łatwego dostępu do informacji, zamieszczania unikatowych treści, regularnych wpisów, zaprezentowania na bieżąco swoich osiągnięć dzięki stworzeniu dobrego profilu w mediach społecznościowych i portalach profesjonalistów. Podobne możliwości daje aktywne uczestniczenie w dyskusjach na forach, które dają możliwość kształtowania zainteresowań. Efektem tego może być rozwijanie czysto amatorskich ambicji młodych ludzi do poznawania określonej dyscypliny lub dziedziny naukowej, pierwszy kontakt z określoną problematyką naukową. Dyskusje mogą się stać źródłem inspiracji i aspiracji do profesjonalnego zajęcia się w przyszłym życiu zawodowym określoną dziedziną i podjęcia pracy naukowej, przyczyniając się tym samym do budowania środowisk naukowych w kraju i na świecie ${ }^{26}$.

Nie można nie docenić w tworzeniu własnej reputacji w sieci wyszukiwarek internetowych. Ułatwiają one odnalezienie osoby zajmującej się naukowo konkretną tematyką badawczą, zwiększają jej dostrzegalność w sieci poprzez odpowiednie pozycjonowanie witryny w najpopularniejszych wyszukiwarkach internetowych. W świecie realnym, jak zauważa P. Sztompka reputacja coraz częściej jest konstruowana, modyfikowana, przedstawiana wybiórczo, oczyszczana ze wstydliwych wydarzeń i wypełniana zmyślonymi elementami w sposób celowy. Istotą takich zabiegów jest zmylenie odbiorcy i dodanie sobie większego uznania.

Jeszcze łatwiej można zafałszować reputacje pośrednią. (...) Przykładem z obszaru nauki może być koteria akademicka, której członkowie piszą pozytywne recenzje badań prowadzonych przez innych i mogą spodziewać się tego samego ze strony

$\overline{25}$ P. Sztompka, Zaufanie. Fundament..., s. 171.

26 Promocja $w$ nauce. Poradnik dobrych praktyk, Ministerstwo Nauki i Szkolnictwa Wyższego, Warszawa 2007, Studenci o priorytetach prezydencji: najważniejsza promocja nauki i kultury (źródło: PAP, 7 lipca 2011). 
kolegów. Podnosi to widoczność całej grupy w oczach szerszej zbiorowości oraz jej reputacji, a każdy z członków dodatkowo zwiększa swoją osobistą reputację przez fakt należenia do grupy cieszącej się znakomita renomą ${ }^{27}$.

Okazuje się, że również w świecie wirtualnym niektóre osoby nie przestrzegają zasad etycznych, potrafią przy użyciu odpowiednich narzędzi dokonać pewnych manipulacji.

To negatywny aspekt korzystania z Internetu dający możliwość manipulowania informacjami ukazującymi się w sieci przez mniej przyzwoitych naukowców, którzy dla poprawienia swojego wizerunku mogą przy użyciu pewnych narzędzi zapewnić sobie brak negatywnych informacji na swój temat w pierwszych 10-20 wynikach wyszukiwania lub zamieszczanie pozytywnych lub neutralnych informacji na swój temat (technika SEO - pozycjonowanie stron i treści na dane słowa kluczowe, które odpowiednio tworzą i kształtują wizerunek). Zasady etyki powinny obowiązywać podczas kreowania własnej reputacji zarówno w świecie realnym jak i wirtualnym. Doskonałą okazją do zaprezentowania swoich publikacji, działań edukacyjnych i doradczych są portale branżowe. Jednym z bardziej interesujących, dających możliwość zaprezentowania się w jak najlepszym świetle poprzez rzetelną systematyczną komunikację z odbiorcami, są blogi prowadzone przez osoby reprezentujące świat nauki. Dzięki nim każda z osób uczestnicząca w świecie internetowym ma możliwość nawiązania kontaktu z naukowcem popularnych publikacji, który staje się bardziej dostępny. Autor bloga, dzięki częstej i systematycznej aktualizacji treści, ma możliwość wykreowania wiarygodnej reputacji według oczekiwań, potrzeb czy możliwości własnych oraz użytkowników sieci. Zawarte opinie czytelników często zmuszają do pewnych refleksji, inspirują do podzielenia się poglądami, przeżyciami. Możliwość budowania eksperckiego wizerunku dzięki zaoferowaniu użytkownikom interesujących treści, poszerzających ich wiedzę, dzielenia się z nimi aktualnymi informacjami czy wreszcie w przypadku cenionych i często „czytanych" blogerów, uznania ich jako liderów opinii. Doskonałym przykładem blogera-naukowca jest Prof. Bogusław Śliwerski. Jak cennym przedsięwzięciem jest systematyczne i zdyscyplinowane prowadzenie przez niego bloga, niech świadczą słowa, potwierdzające powyższe stwierdzenia, wygłoszone przez Prof. Teresę Hejnicką-Bezwińską

$\overline{27}$ P. Sztompka, Zaufanie. Fundament..., s. 173. 
podczas uroczystości nadania Prof. Bogusławowi Śliwerskiemu tytułu Doktora Honoris Causa Uniwersytetu Kazimierza Wielkiego

Nie można zakończyć omawiania dokonań Profesora Śliwerskiego bez przywołania jego zasług związanych z prowadzeniem blogu od września 2009 roku. Różne są powody popularności i sięgania ludzi do poszczególnych postów, ale ich brak zdecydowanie pogorszyłby nasze wspólnotowe funkcjonowanie jako środowiska zainteresowanego pedagogiką i edukacją w świecie nadmiaru danych, informacji i wiedzy ${ }^{28}$.

Wskazana tu została szczególnie funkcja integrowania środowiska naukowego oraz bycia przewodnikiem po trudnych, często zaśmieconych drogach komunikacji internetowej. To najlepszy dowód na to, jak ważne jest wykorzystywanie dostępnych narzędzi internetowych przez naukowców wiarygodnej reputacji.

\section{Podsumowanie}

Internet będący przykładem nowoczesnej technologii tworzy nową jakość komunikowania, dzięki której dochodzi do bardziej dynamicznych relacji przedstawicieli nauki z jej odbiorcami. Popularyzacja działań naukowych poprzez Internet stała się znaczącym czynnikiem kreowania reputacji będącej sumą cząstkowych, nagromadzonych w czasie wizerunków. Stawia to nowe wyzwania przed naukowcami, podjęcia przemyślanych, systematycznych działań w kierunku zarządzania własną reputacją. Możliwości prezentowania osiągnięć, nie tylko przy pomocy tradycyjnych metod, jak np. rozpowszechnianie wyników badań przez publikacje naukowe czy konferencje, ale również dzięki narzędziom internetowym, takim jak: strona www, fanpage na Facebooku lub innym portalu społecznościowym, portale branżowe, fora dyskusyjne, blogi czy też wyszukiwarki internetowe, stały się dziś znacznie bardziej dynamiczną formą, która pozwala docierać do szerszego grona odbiorców. Dobra reputacja zachęca innych do podejmowania współpracy, z której korzyści czerpią nie tylko naukowcy,

28 T. Bezwińska-Hejnicka, Laudacja z okazji nadania profesorowi doktorowi habilitowanemu Bogusławowi Śliwerskiemu tytułu Doktora Honoris Causa Uniwersytetu Kazimierza Wielkiego. Acta Universitatis Casimiri Magni Doctores Honoris Causa, Wydawnictwo UKW, Bydgoszcz 2016, s. 29. 
ale i druga strona współdziałająca. Wykorzystywanie Internetu do zarządzania reputacją umożliwia „nie tylko orientację w działaniach podejmowanych przez środowiska naukowe, ale także podejmowanie dyskusji, a tym samym spojrzenia na określony temat szerzej i z różnych perspektyw. Media jako forum wymiany doświadczeń, opinii naukowców są dla odbiorców dodatkową okazją do zdobywania i poszerzania wiedzy. Profity są więc obopólne dzięki intensywnej ekspozycji wspólnych osiągnięć. Warto wskazać na bardziej globalną korzyść płynącą z kreowania pozytywnej reputacji naukowców, a tym samym jednostek zajmujących się nauką, w których pracują. Jest to wzrost tożsamości i poczucie dumy z przynależenia do społeczeństwa uzyskującego wybitne osiągnięcia w różnych dziedzinach nauki. A dzieje się tak, dzięki znajomości i docenianiu wartości działań prezentowanych przez grono naukowców za pomocą narzędzi internetowych.

\begin{abstract}
The article aims at drawing attention to opportunities of reputation management by researchers using new media, considering the importance of internet tools for image creation and identifying opportunities and threats. The research problem of the article focuses on answers to the question formulated as follows: What might the possible importance of the Internet for reputation building be? The problem relates to the issue of researchers' active participation in creating and shaping their reputation online. The presented considerations have been based on literature and studies on the subject. The article attempts to clarify the distinction between the concepts of identity, image, and reputation. It discusses image-creating factors and refers to the question of immanent credibility and guise in research. The author describes examples of internet tools and points to their importance for reputation management, which concerns the sum of partial images accumulating over time. Communication plays an important role in building reputation. Owing to its availability, interactivity and variety of forms, as well as the speed of information transfer, the Internet has become an indispensable channel of communication. All researchers should recognise the fact in order to build their reputation thoughtfully. Their reputation involves a multitude of accumulated images formed as a result of interactions between factors associated with the subjects themselves, information the recipients obtain, and factors relating to the recipients. The conclusions of the study point to the necessity of reputation management by planned and deliberate actions taking advantage of internet tools. Thus, every effort should be
\end{abstract}


made to prevent a situation where reputation is shaped irrespective of the interested person's participation.

\section{Bibliografia}

Altkorn J., Kształtowanie rynkowego wizerunku firmy, Wydawnictwo Akademii Ekonomicznej, Kraków 2009.

Bezwińska-Hejnicka T., Laudacja z okazji nadania profesorowi doktorowi habilitowanemu Bogusławowi Śliwerskiemu tytułu Doktora Honoris Causa Uniwersytetu Kazimierza Wielkiego, „Acta Universitatis Casimiri Magni Doctores Honoris Causa", Wydawnictwo UKW, Bydgoszcz 2016.

Britt S.H., Psychological Principles of the Corporate Imagery Mix, „Business Horizons" 1971, 14/1.

Dąbrowski T., Rola mediów w kształtowaniu wizerunku, „Marketing i Rynek" 2013, nr 9.

Goćkowski J., Ethos nauki i role uczonych, Wydawnictwo i Drukarnia Secesja, Kraków 1996.

Głuszek E., Kreowanie reputacji przedsiębiorstwa w mediach społecznościowych-szanse i zagrożenia, „Zarządzanie i Finanse”2013, nr 4/1.

Głuszek E., Kreowanie reputacji przedsiębiorstwa w sieci-nowe możliwości komunikowania z interesariuszami. [w:] J. Skalik, A. Wierzbic, M. Wąsowicz (red.), Trendy transformacji modelu organizacyjnego przedsiębiorstwa, Wydawnictwo Uniwersytetu Ekonomicznego, Wrocław 2012.

Hardin R., Zaufanie, przekł. A. Gruba, Wydawnictwo Sic!, Warszawa 2009.

Majchrzak K., Zarządzanie reputacją korporacyjna we współczesnej gospodarce, [w:] R. Maćkowska, H. Przybylski (red.), Public relations - aktualne zagadnienia sztuki komunikowania $w$ teorii $i$ praktyce, Wydawnictwo Akademii Ekonomicznej, Katowice 2009.

Pawiak A., Cyberprzestrzeń jako „forum" oddziałujące na młode pokolenia w refleksji Jana Pawła II, „Rozprawy Społeczne” 2015, nr 9/4.

Piekarski J., Dlaczego pytamy o wiarygodność? Pogranicza dyscyplinarne w praktyce akademickiej. [w:] J. Piekarski, D. Urbaniak-Zając (red.), Wiarygodność akademicka w edukacyjnych praktykach, Wydawnictwa Uniwersytetu Łódzkiego, Łódź 2016.

Promocja w nauce. Poradnik dobrych praktyk, Ministerstwo Nauki i Szkolnictwa Wyższego, Warszawa 2007.

Pruchnicka J., Media Relations - promocja nauki i instytucji badawczych $w$ mediach $w$ Polsce $i$ Europie, „Marketing Instytucji Naukowych i Badawczych" 2012, nr 1(2). 
Sampson E., Jak tworzyć własny wizerunek, przekł. A. Białkowska-Gużyńska, Dom Wydawniczy ABC, Warszawa 1996.

Sztompka P., Zaufanie. Fundament społeczeństwa, Wydawnictwo Znak, Kraków 2007.

Wieseneder S., Cerny T., Skuteczne zarządzanie reputacją i spójny image, Wydawnictwo BestPress, Warszawa 2008.

Witkowski L., Wyzwania autorytetu w praktyce społecznej i kulturze symbolicznej, Oficyna Wydawnicza „Impuls”, Kraków 2009. 